\title{
Examination of the 2023 Education Vision Document in Terms of Teachers and School Administrators' Views: The Case of Kahramanmaraş Province
}

\author{
Hulusi Eryilmaz ${ }^{1} \quad$ Mehmet Ali Hamedoğlu ${ }^{2}$
}

\begin{abstract}
This study was carried out in order to determine the applicability of the 2023 Education Vision in institutions affiliated to the Ministry of National Education from the perspective of education administrators and teachers. Our research population consists of school administrators and teachers in Kahramanmaraş Province. In this study, which is made by taking samples from the universe, the case consists of 403 participants among the total participants who fill the questionnaire form completely. $\mathrm{h}$ data were obtained by benefiting from the attitudes and opinions of school administrators and teachers regarding the 2023 education vision. The positive and negative aspects of the system were investigated in the context of the 2023 Education Vision. The positive and negative aspects of the system were investigated in the context of the 2023 Education Vision. As a result of the analysis, it was determined that teachers and administrators were mostly aware of the objectives of the 2023 Education Vision Document but were not invited to any meeting before the vision document was announced. It was determined that factors such as gender, age, marital status, working environment and places of residence do not affect teachers' opinions about the 2023 Education Vision. On the other hand, it has been found that teachers with a high socioeconomic level have higher beliefs in Education Vision than others.
\end{abstract}

Keywords: Education, 2023 Education Vision, Vision, National Ministry of Education, Technologies

\section{Introduction}

With the digital age we have just met, the concepts of school and education are heading for a new meaning. Families and students calculate to the finest detail the educational conditions of each profession and the difficulties that young people may encounter in the process of starting life. The function and definition of school, teacher and education are changing rapidly in terms of needs (Arslan \& Ozpinar, 2018). The effort to renew education that started in the late 1990s, close examination of student exchange programs and Western-style education models since the 2000s, unsuccessful results in exams such as PISA, PIRLS, TIMMS in which student competencies are measured at the international level, and finally, starting the Covid-19 epidemic in 2019, continuing to be experienced in our country and in the whole world with deep effects, a very rapid change has begun in the roles of teachers, students, ministry and parents in our country's education system. (Erturk, 2019, Celik, 1995) Increasing

\footnotetext{
${ }^{1}$ MA, Sakarya University, Institute of Education Sciences, Turkey, hulusi_0909@hotmail.com, ORCID: https://orcid.org/0000-0002-5910-8652

2 Assoc. Dr., Sakarya University, Faculty of Education, Turkey, mhamed@sakarya.edu.tr, ORCID: https://orcid.org/0000-0003-2833-2931
} 
expectations of people from the education system day by day increases the pressure on the education system (General Directorate of Education Reform, 2011).

It is an undeniable fact that the countries that were successful in the education system in the 1950s have written their names among the strongest states in the world until the 2000s. Both our country and other countries of the world have entered a fierce race in the field of education from the beginning of the twenty-first century, using all their experiences of the last century. The German Education System, which has been distinguished since the second half of the twentieth century, is the most important example of this. After the defeat in the 2nd World War, Germany achieved an important success with the vision move it made in the education system. As a result of this success, Germany succeeded in completing its development and development between 1950-1980. The production move based on technical and vocational education has made the German economy one of the few economies in the world (Ergun, 2018). The fact that by investing in education, you can have a voice around the world is still valid. (Akyüz, 2011). For this reason, every society that envisions a future must create an education system that will meet the needs of this age. It is inevitable that countries that cannot achieve success in this area will face the threat of poverty and vulnerability in the near future. It should not be difficult to know that the countries that are taking immediate action to renew the education system aim to be countries where richer, more secure and wealthy people live than other countries of the world. It is not easy to restore any ecosystem while it is up and running. It is even more difficult to decide on such a change in the education ecosystem and to act on it. The cost of a standstill in an education system, which is directly linked to many different fields, can be much higher than anticipated. In this process, it is necessary to keep in mind that the desire for change can only be achieved if individuals or societies assimilate their new roles and act willingly (Sergiovanni, 1994).

In some countries of the world that realized the existence of this need with our country, various movements of change in the field of education have started. In the first quarter of the twenty-first century, educational vision documents, in which various goals were highlighted in countries such as Australia, Brazil, China, England, and South Africa, were completed and published (Hamarat \& Arıkan, 2018). The comparison of the distance traveled by other countries that issued an education vision document with the distance traveled in our country seems very intriguing. Turkey variables of this kind of work will be put out by this and similar studies.

The most important tool people and organizations use for change is vision. Vision word according to Turkish Language Institute Dictionary; it means appearance, ideal, prudence, demonstration, foresight. According to Erçetin (2000), the concept of vision is the dominant element of new leadership approaches with intellectual and operational dimensions.

Result documents, which are photographs of vision studies, are called vision documents. Vision documents are declarative texts in which organizations put forward the processes and objectives of developing and sharing a certain vision. According to Şişman (2002), it is necessary to clearly reveal what the goals of the vision shared with other common discourse are. Vision documents can be said to be a decree and a declaration of will in these aspects. Vision documents are documents used to reveal the medium and long term goals that organizations have set to achieve common goals. In this sense, it is possible to say that the first written vision document in the history of Turkish Education is the Gokturk Inscriptions. The ability of organizations to strengthen and develop their missions depends on 
developing a healthy vision. According to Senge (1993), the common vision is more than just a good idea, a factor is a force. Success in vision development means sharing the vision in a healthy way; sharing the vision depends on the correct language of the organization from the top to the lowest unit. It is not possible to agree with the thoughts that Hamarat and Arikan's (2018) vision document is encouraging. The concept of incentive, rather than qualifying the vision document that is the result of the vision, is an important tool to consider for stakeholders in the process of sharing the vision.

The 2023 Education Vision Document is a document created to meet the vision needs of the education system, which has been considered a major problem in our country for many years. With this research, it is aimed to evaluate the 2023 Education Vision Document from the eyes of teachers and school administrators, based on the province of Kahramanmaras. To what extent has the new education vision, which has been implemented by the Ministry of National Education for the first time since 2019, has been accepted and supported by teachers and school administrators; It was tried to reach the answers to the questions such as whether the implementations carried out in 2019 and 2020 are aimed at the vision goals, is the vision a shared vision or is it a package study prepared directly by the ministry. Also, does this document really promise to solve the problems of the Turkish Education System? With the question, it is wanted to reach a healthy opinion about the future of education vision. During the survey study, the participants expressed many negative opinions, especially on sharing the vision. Most of the participating teachers regretted that they were not invited to any vision meetings. However, dozens of studies in the literature are skeptical about the success of the unshared vision. We think that it is beneficial to make a situation assessment for the 2023 Education Vision Document by the Turkish Education System in these days when digitalization has become almost mandatory.

In such important vision studies, it is extremely important to listen carefully and to get their opinions from every stakeholder of the education ecosystem. It is seen that teachers' opinions are not taken into account in the vision development process for the 2023 Education Vision Document. It was also observed from the dialogues in the field that the teachers were upset with the ministry due to this situation. However, we can state that we have also observed that during the unexpected Covid-19 epidemic process, teachers put their resentment aside and act with a sense of service to the country. This situation may even be considered as an opportunity that the ministry can use to adapt teachers to the vision. Communication with teachers who seem neglected prior to the release of the vision document should be re-evaluated.

Understanding and embracing the vision and reaching the farthest reaches of the education system; in short, in order to achieve success, the vision must first be shared with teachers. On the other hand, it is seen that the 2023 Education Vision Document published by the Ministry of National Education has reached a high horizon in terms of its content and scope. One of the few comprehensive educational movement in Turkey's history that it is possible to express. The 2023 Education Vision Document is a valuable and important study in terms of its content and objectives. Although the extent to which the vision is shared is discussed with strong expressions, we can say that it is an important litmus in terms of providing inspiration and experience to future great vision moves. Even if the idea that the Turkish Education ecosystem will solve all its problems in the short term does not sound convincing to anyone, it should be regarded as the cornerstone of a positive momentum to be achieved in the near future. Thanks to this document, it is possible to open the doors of many innovations, albeit gradually. 


\section{Method}

In this study, the simple scanning model that aims to describe the situation that has been going on from the past to the present in its current form was used.

\section{Study Group}

The reason for the study and how to fill the scale was explained by interviewing the teachers and school administrators in 33 primary schools in Kahramanmaras. 435 of the 443 questionnaire forms that were distributed were received, and 403 of the 435 forms in hand were analyzed on the computer. Of the 403 participants, 361 were teachers and 42 were school administrators. According to Yazicioglu and Erdogan (2004, p.50), "A sample of 378 people with a margin of error of 0.05 represents a universe of 25,000 people." Therefore, it is thought that the sample reached in this study may represent the universe.

\section{Data Collection Tool}

In the study, it was concluded that collecting data with the questionnaire form would be much more efficient than other data collection tools in terms of time use and access to the most up-to-date opinions. For this reason, School Administrators Education Vision Measurement Questionnaire (SAEVMQ) and Teacher Education Vision Measurement Questionnaire (TEVMQ) were prepared in order to obtain the opinions of primary school administrators and teachers.

The attitudes and opinions of school administrators and teachers regarding the 2023 Education Vision were used in the collection of research data. The permissions of the scales were obtained and applied beforehand. In the application of the scales, the data obtained on a voluntary basis were kept confidential.

The tool used to collect the data of the research was used separately for school administrators and teachers, with the first seven questions and two different questionnaires with the same two parts. School Administrators Education Vision Survey (SAEVMQ) and Teacher Education Vision Measurement Questionnaire (TEVMQ) consist of four sections.

In the first sections of both surveys, in accordance with the literature, in the first seven questions, questions were asked to collect information about whether the managers and teachers had information about the 2023 Education Vision Document, whether they supported the vision study. Questions were asked such as being aware of the objectives of the 2023 Education Vision Document, knowing its slogan, knowing the vision sentence, whether opinions were asked before the vision document was announced, whether they were invited to the meetings. In the second part of the questionnaire, the participants were asked questions such as whether they support the vision document, whether they are excited for the results of the vision document, and whether they support its success.

In the third part of SAEVMQ, two evaluation questions related to the purpose of making the education system data-based in the 2023 Education Vision Document, and in the fourth part, questions regarding changes in human resources, financing, corporate guidance and inspection management were asked. SAEVMQ consists of a total of fifteen questions. In the third part of the TEVMQ, teachers' opinions about the effect of vision applications on the student were tried to be determined and the participants were asked questions such as whether they believe that the 2023 Education Vision Document increases the effectiveness of measurement methods and whether it will contribute to the student's social 
activities. In the fourth part of the TEVMQ, it was tried to determine whether the 2023 Education Vision Document brought innovations in terms of the teaching profession and four questions were asked about it. TEVMQ consists of seventeen questions.

\section{Data Collection}

In order to collect the data, the schools were visited by obtaining the necessary permissions from the Kahramanmaras Provincial Directorate of National Education. A questionnaire was conducted between 02.03.2020 and 13.03.2020 with 361 classroom teachers and 42 school administrators working in 23 primary schools in Kahramanmaras.

\section{Data Analysis}

Frequency (f) and percentages (\%) were used to determine the resulting variables by considering demographic information. Item totals and averages of the dimensions of the scales were found. Means and standard deviations were calculated. Independent sample t-test and one-way variance (ANOVA) analyzes were conducted to determine whether the School Administrators' and Teachers' opinions on the Education Vision for 2023 differ according to demographic variables. Correlation analysis was conducted to find the relationship between the attitude and opinion levels of School Administrators and Teachers about the 2023 Education Vision. In the tests, the level of significance (Sig.) was determined as 0.05 , and this value and below was interpreted as meaningful.

\section{Reliability Analysis}

Cronbach Alpha Coefficient was used to measure the reliability of the analyzed data in the study. The Alpha coefficient, which is found by proportioning the total variances of the questions in the test used in the study to the general variance and takes values between 0 and 1 , is a weighted standard average of change. The Cronbach Alpha Coefficient, which investigated whether the questions in the test form a whole to explain a homogeneous structure, was found to be in the range of $0.60-0.80$ and was quite reliable. In this study, the Cronbach Alpha Coefficient of 0.91 was found to be quite high.

\section{Findings}

The findings of the study were evaluated over the problem statement and tables related to subproblems. The problem sentence of the research is what are the opinions of primary school administrators and teachers regarding the 2023 Education Vision Document. Findings about the attitudes and views of the school administrators are given in the first table below and the teachers' attitudes and views in Table 1.

The school administrators who participated in the study were 4 (9.5\%) are female and $38(90.5 \%)$ are male. Most of the school administrators participating in the study are male. It was determined that 198 $(54.8 \%)$ of the teachers participating in the study were female and $163(45.2 \%)$ were male. Most of the teachers participating in the study are women. In this context, although the majority of teachers are women, the fact that school administrators are predominantly male is a striking situation that needs to be investigated. 


\section{Table 1}

School Administrators' Attitudes and Views on the 2023 Education Vision

\begin{tabular}{|c|c|c|c|}
\hline & $\mathrm{N}$ & $\bar{x}$ & SD \\
\hline Being aware of the document & 42 & 1.40 & .497 \\
\hline Being aware of the slogan & 42 & 1.71 & .742 \\
\hline Being aware of the vision sentence & 42 & 1.79 & .925 \\
\hline Giving opinion to the vision & 42 & 2.90 & 1.185 \\
\hline Participating in vision meetings & 42 & 3.14 & 1.280 \\
\hline Excited for the vision & 42 & 2.05 & .962 \\
\hline Supporting the vision & 42 & 1.60 & .701 \\
\hline Believing that ministry decisions are based on data & 42 & 2.02 & .680 \\
\hline Believing that decisions made at school are based on data & 42 & 2.14 & .926 \\
\hline Believing that educators are starting a career plan & 42 & 2.26 & .964 \\
\hline Believing that the human resources of the school have become efficient & 42 & 2.12 & .968 \\
\hline Believing that awards are being given fairly & 42 & 3.07 & 1.113 \\
\hline Believing that funding sources are getting stronger & 42 & 3.00 & .988 \\
\hline Believing that guidance services are improving & 42 & 2.29 & 1.019 \\
\hline Believing that inspection services are being renewed & 42 & 2.45 & 1.041 \\
\hline
\end{tabular}

When the table above is examined, it is understood that the school administrators participating in the study were somewhat aware of the objectives of the education vision document, but some were not invited to the meetings during the vision preparation process. All of the 42 school administrators who participated in the survey stated that they were aware of the aims of the document. The answers given by the participants to the questionnaire questions consist of the highest average (1.40) and the answers given to the question whether they are aware of the objectives of the 2023 Education Vision Document. The lowest average (3.14) was the question of whether they were invited to meetings before the announcement of the 2023 Education Vision Document. According to the answers received, all of the managers participating in the research stated that they were aware of the 2023 Education Vision Document, but they were not invited to any meeting before the document was announced. 


\section{Table 2}

Teachers' Attitudes and Views on the 2023 Education Vision

\begin{tabular}{llll}
\hline & $\mathrm{N}$ & $\bar{x}$ & $\mathrm{SD}$ \\
\hline Being aware of the document & 361 & 1.81 & .679 \\
Being aware of the slogan & 361 & 2.16 & .937 \\
Being aware of the vision sentence & 361 & 2.11 & .947 \\
Giving opinion to the vision & 361 & 3.41 & 1.109 \\
Participating in vision meetings & 361 & 3.52 & 1.138 \\
Excited for the vision & 361 & 2.52 & 1.062 \\
Supporting the vision & 361 & 1.83 & .781 \\
Believing in the effectiveness of measurement methods & 361 & 2.31 & .852 \\
Believing in the effectiveness of evaluation methods & 361 & 2.32 & .850 \\
Being aware of the social development of the student & 361 & 2.03 & .743 \\
Is not aware of the cultural development of the student & 361 & 2.04 & .774 \\
Believe that the student is relieved of the test pressure & 361 & 2.53 & .937 \\
Believing that vision drives healthy data flow in school & 361 & 2.67 & .989 \\
Believing that vision contributes to a professional career plan & 361 & 3.15 & 1.060 \\
Believing that vision provides proficiency in measuring & 361 & 2.83 & .965 \\
Believing that the vision provides competence in evaluation & 361 & 2.82 & .950 \\
\hline
\end{tabular}

Among the answers given by teachers to the questions regarding the 2023 Education Vision Document, the highest average (1.81) is that they are aware of the objectives of the 2023 Education Vision Document. On the other hand, teachers replied that with an average of 3.52 (3.52), they were not invited to the meetings before the announcement of the 2023 Education Vision Document. From the table above, it is understood that the teachers who participated in the survey were aware of the aims of the education vision document, but were not invited to any meeting during the vision preparation process. 


\section{Table 3}

The Relationship Between School Administrators' Views on the 2023 Education Vision and the Socioeconomic Status Variable

\begin{tabular}{|c|c|c|c|c|c|}
\hline & & $\mathrm{N}$ & $\bar{x}$ & SD & $p$ \\
\hline \multirow{4}{*}{ Being aware of the document } & High & 10 & 1.40 & .516 & \multirow{4}{*}{601} \\
\hline & Middle & 8 & 1.25 & .463 & \\
\hline & Low & 24 & 1.46 & .509 & \\
\hline & Total & 42 & 1.40 & .497 & \\
\hline \multirow{4}{*}{ Being aware of the slogan } & High & 10 & 1.50 & .527 & \multirow{4}{*}{.585} \\
\hline & Middle & 8 & 1.75 & .707 & \\
\hline & Low & 24 & 1.79 & .833 & \\
\hline & Total & 42 & 1.71 & .742 & \\
\hline \multirow{4}{*}{ Being aware of the vision sentence } & High & 10 & 1.40 & .516 & \multirow{4}{*}{.051} \\
\hline & Middle & 8 & 1.38 & .518 & \\
\hline & Low & 24 & 2.08 & 1.060 & \\
\hline & Total & 42 & 1.79 & .925 & \\
\hline \multirow{4}{*}{ Giving opinion to the vision } & High & 10 & 2.40 & 1.075 & \multirow{4}{*}{.148} \\
\hline & Middle & 8 & 3.50 & 1.069 & \\
\hline & Low & 24 & 2.92 & 1.213 & \\
\hline & Total & 42 & 2.90 & 1.185 & \\
\hline \multirow{4}{*}{ Participating in vision meetings } & High & 10 & 3.00 & 1.155 & \multirow{4}{*}{.914} \\
\hline & Middle & 8 & 3.25 & 1.389 & \\
\hline & Low & 24 & 3.17 & 1.341 & \\
\hline & Total & 42 & 3.14 & 1.280 & \\
\hline \multirow{4}{*}{ Excited for the vision } & High & 10 & 1.70 & .483 & \multirow{4}{*}{.165} \\
\hline & Middle & 8 & 1.75 & .707 & \\
\hline & Low & 24 & 2.29 & 1.122 & \\
\hline & Total & 42 & 2.05 & .962 & \\
\hline \multirow{4}{*}{ Supporting the vision } & High & 10 & 1.60 & 699 & \multirow{4}{*}{.606} \\
\hline & Middle & 8 & 1.38 & .518 & \\
\hline & Low & 24 & 167 & 761 & \\
\hline & Total & 42 & 1.60 & .701 & \\
\hline
\end{tabular}




\begin{tabular}{|c|c|c|c|c|c|}
\hline \multirow{4}{*}{$\begin{array}{l}\text { Believing that ministry decisions are } \\
\text { based on data }\end{array}$} & High & 10 & 2.00 & .667 & \multirow{4}{*}{.758} \\
\hline & Middle & 8 & 1.88 & .835 & \\
\hline & Low & 24 & 2.08 & .654 & \\
\hline & Total & 42 & 2.02 & .680 & \\
\hline \multirow{4}{*}{$\begin{array}{l}\text { Believing that decisions made at } \\
\text { school are based on data }\end{array}$} & High & 10 & 1.90 & .738 & \multirow{4}{*}{.021} \\
\hline & Middle & 8 & 1.50 & .756 & \\
\hline & Low & 24 & 2.46 & .932 & \\
\hline & Total & 42 & 2.14 & .926 & \\
\hline \multirow{4}{*}{$\begin{array}{l}\text { Believing that educators are } \\
\text { starting a career plan }\end{array}$} & High & 10 & 2.10 & .738 & \multirow{4}{*}{.284} \\
\hline & Middle & 8 & 1.88 & .835 & \\
\hline & Low & 24 & 2.46 & 1.062 & \\
\hline & Total & 42 & 2.26 & .964 & \\
\hline \multirow{4}{*}{$\begin{array}{l}\text { Believing that the human resources of the school } \\
\text { have become efficient }\end{array}$} & High & 10 & 1.90 & .568 & \multirow{4}{*}{.013} \\
\hline & Middle & 8 & 1.38 & .518 & \\
\hline & Low & 24 & 2.46 & 1.062 & \\
\hline & Total & 42 & 2.12 & .968 & \\
\hline \multirow{4}{*}{$\begin{array}{l}\text { Believing that awards are being } \\
\text { given fairly }\end{array}$} & High & 10 & 3.70 & 1.160 & \multirow{4}{*}{.092} \\
\hline & Middle & 8 & 2.63 & .916 & \\
\hline & Low & 24 & 2.96 & 1.083 & \\
\hline & Total & 42 & 3.07 & 1.113 & \\
\hline \multirow{4}{*}{$\begin{array}{l}\text { Believing that funding sources } \\
\text { are getting stronger }\end{array}$} & High & 10 & 3.10 & .568 & \multirow{4}{*}{.288} \\
\hline & Middle & 8 & 2.50 & 1.069 & \\
\hline & Low & 24 & 3.13 & 1.076 & \\
\hline & Total & 42 & 3.00 & .988 & \\
\hline \multirow{4}{*}{ Believing that guidance services are improving } & High & 10 & 2.20 & .789 & \multirow{4}{*}{.805} \\
\hline & Middle & 8 & 2.13 & .991 & \\
\hline & Low & 24 & 2.38 & 1.135 & \\
\hline & Total & 42 & 2.29 & 1.019 & \\
\hline \multirow{4}{*}{$\begin{array}{l}\text { Believing that inspection services are } \\
\text { being renewed }\end{array}$} & High & 10 & 2.00 & .471 & \multirow{4}{*}{.163} \\
\hline & Middle & 8 & 2.25 & 1.165 & \\
\hline & Low & 24 & 2.71 & 1.122 & \\
\hline & Total & 42 & 2.45 & 1.041 & \\
\hline
\end{tabular}


The relationship between the opinions of the participants on the 2023 Education Vision and the socioeconomic status variable has been tried to be presented in the table above. Accordingly, school administrators participating in the survey for each socioeconomic level report that their decisions have begun to be made based on data with the 2023 Education Vision Document. In addition, with the vision document, a high average (0.56) has been obtained that the human resources in schools are made stronger and more efficient. With the view that innovations have started in inspection services (0.47), it has been realized at a very high rate. Accordingly, with the 2023 Education Vision Document, there is a prevalent opinion that significant changes have been made in inspection services in a positive way.

\section{Table 4}

The Relationship Between School Administrators' Views on the 2023 Education Vision and the Title Variable

\begin{tabular}{|c|c|c|c|c|c|}
\hline & Position & $\mathrm{N}$ & $\bar{x}$ & $\mathrm{SD}$ & $p$ \\
\hline \multirow{2}{*}{ Being aware of the document } & Director & 13 & 1.23 & .439 & \multirow{2}{*}{.002} \\
\hline & DD & 29 & 1.48 & .509 & \\
\hline \multirow{2}{*}{ Being aware of the slogan } & Director & 13 & 1.46 & .519 & \multirow[t]{2}{*}{.345} \\
\hline & DD & 29 & 1.83 & .805 & \\
\hline \multirow{2}{*}{ Being aware of the vision sentence } & Director & 13 & 1.92 & 1.115 & \multirow[t]{2}{*}{.294} \\
\hline & DD & 29 & 1.72 & .841 & \\
\hline \multirow{2}{*}{ Giving opinion to the vision } & Director & 13 & 2.85 & 1.144 & \multirow[t]{2}{*}{.562} \\
\hline & DD & 29 & 2.93 & 1.223 & \\
\hline \multirow{2}{*}{ Participating in vision meetings } & Director & 13 & 2.62 & 1.387 & \multirow{2}{*}{.387} \\
\hline & DD & 29 & 3.38 & 1.178 & \\
\hline \multirow{2}{*}{ Excited for the vision } & Director & 13 & 1.92 & 1.188 & \multirow[t]{2}{*}{.313} \\
\hline & $\mathrm{DD}$ & 29 & 2.10 & .860 & \\
\hline \multirow{2}{*}{ Supporting the vision } & Director & 13 & 1.54 & .660 & \multirow[t]{2}{*}{.874} \\
\hline & $\mathrm{DD}$ & 29 & 1.62 & .728 & \\
\hline \multirow{2}{*}{ Believing that ministry decisions are based on data } & Director & 13 & 2.00 & .816 & \multirow[t]{2}{*}{.190} \\
\hline & $\mathrm{DD}$ & 29 & 2.03 & .626 & \\
\hline \multirow{2}{*}{ Believing that decisions made at school are based on data } & Director & 13 & 2.15 & .899 & \multirow{2}{*}{.728} \\
\hline & DD & 29 & 2.14 & .953 & \\
\hline \multirow{2}{*}{ Believing that educators are starting a career plan } & Director & 13 & 2.38 & .961 & \multirow{2}{*}{.946} \\
\hline & $\mathrm{DD}$ & 29 & 2.21 & .978 & \\
\hline
\end{tabular}




\begin{tabular}{lllllll}
\hline $\begin{array}{l}\text { Believing that the human resources of the school have } \\
\text { become efficient }\end{array}$ & Director & 13 & 2.23 & 1.013 & \\
\hline & DD & 29 & 2.07 & .961 & .591 \\
Believing that awards are being given fairly & Director & 13 & 3.08 & 1.188 & .734 \\
\hline & DD & 29 & 3.07 & 1.100 & \\
\hline Believing that funding sources are getting stronger & Director & 13 & 2.92 & .862 & \\
\hline & DD & 29 & 3.03 & 1.052 & .291 \\
Believing that guidance services are improving & Director & 13 & 2.15 & 1.214 & \\
\hline & DD & 29 & 2.34 & .936 & \\
\hline Believing that inspection services are being renewed & Director & 13 & 2.54 & 1.198 & \\
& DD & 29 & 2.41 & .983 & \\
\hline
\end{tabular}

According to the table above, when the titles of the participants and their views on the 2023 Education Vision are compared, it is understood that school administrators with different titles are aware of the objectives of the 2023 Education Vision Document. All managers (0.41) reported that they were aware of the 2023 Education Vision Document, and they gave negative answers to questions such as being invited to the meetings (1.28), fair distribution of the awards (1.14).

\section{Table 5}

The Relationship between Teachers' Opinions on the Education Vision for 2023 and the Gender Variable

\begin{tabular}{lllllll}
\hline & Sex & N & $\bar{x}$ & SD & $p$ \\
\hline Being aware of the document & Female & 198 & 1.86 & .673 & \\
& Male & 163 & 1.74 & .681 & \\
\hline \multirow{2}{*}{ Being aware of the slogan } & Female & 198 & 2.30 & .976 & \\
& Male & 163 & 1.98 & .857 & \\
\hline Being aware of the vision sentence & Female & 198 & 2.23 & .968 & \\
& Male & 163 & 1.96 & .902 & \\
\hline \multirow{2}{*}{ Giving opinion to the vision } & Female & 198 & 3.38 & 1.068 & \\
& Male & 163 & 3.44 & 1.160 & .111 \\
\hline Participating in vision meetings & Female & 198 & 3.43 & 1.146 & \\
& Male & 163 & 3.64 & 1.121 & \\
\hline Excited for the vision & Female & 198 & 2.43 & .973 & .007
\end{tabular}




\begin{tabular}{|c|c|c|c|c|c|}
\hline & Male & 163 & 2.63 & 1.155 & \\
\hline \multirow[b]{2}{*}{ Supporting the vision } & Female & 198 & 1.88 & .716 & \multirow[b]{2}{*}{.006} \\
\hline & Male & 163 & 1.77 & .850 & \\
\hline \multirow{2}{*}{ Believing in the effectiveness of measurement methods } & Female & 198 & 2.27 & .816 & \multirow{2}{*}{.133} \\
\hline & Male & 163 & 2.36 & .894 & \\
\hline \multirow{2}{*}{ Believing in the effectiveness of evaluation methods } & Female & 198 & 2.24 & .788 & \multirow{2}{*}{.005} \\
\hline & Male & 163 & 2.41 & .914 & \\
\hline \multirow{2}{*}{ Being aware of the social development of the student } & Female & 198 & 2.01 & .730 & \multirow{2}{*}{.170} \\
\hline & Male & 163 & 2.06 & .759 & \\
\hline \multirow{2}{*}{ Being aware of the cultural development of the student } & Female & 198 & 2.02 & .764 & \multirow{2}{*}{.363} \\
\hline & Male & 163 & 2.07 & .787 & \\
\hline \multirow{2}{*}{ Being aware of the physical development of the student } & Female & 198 & 2.03 & .796 & \multirow{2}{*}{.190} \\
\hline & Male & 163 & 2.10 & .821 & \\
\hline \multirow{2}{*}{ Believe that the student is relieved of the test pressure } & Female & 198 & 2.43 & .862 & \multirow{2}{*}{.057} \\
\hline & Male & 163 & 2.64 & 1.010 & \\
\hline \multirow{2}{*}{ Believing that vision drives healthy data flow in school } & Female & 198 & 2.61 & .959 & \multirow{2}{*}{.376} \\
\hline & Male & 163 & 2.74 & 1.022 & \\
\hline \multirow{2}{*}{ Believing that vision contributes to a professional career plan } & Female & 198 & 3.13 & 1.058 & \multirow{2}{*}{.897} \\
\hline & Male & 163 & 3.18 & 1.065 & \\
\hline \multirow{2}{*}{ Believing that vision provides proficiency in measuring } & Female & 198 & 2.81 & .936 & \multirow{2}{*}{.388} \\
\hline & Male & 163 & 2.85 & 1.001 & \\
\hline \multirow{2}{*}{ Believing that the vision provides competence in evaluation } & Female & 198 & 2.83 & .946 & \multirow{2}{*}{.789} \\
\hline & Male & 163 & 2.82 & .957 & \\
\hline
\end{tabular}

In the table above, whether the teachers participating in the research know what the vision document is or not; the gender variable was compared with the questions of whether they knew what the vision statement was and whether they were excited about the results of the vision document. Considering the results, it is seen that the opinions of the teachers of different genders regarding the 2023 Education Vision are positive and their level of opinion is mostly the same. When the relationship between the vision document and the beginning of making career plans for teachers is examined, it is seen that both male and female teachers answered this question negatively with an average (1.06). 


\section{Table 6}

The Relationship between the Opinions of Teachers on the Education Vision for 2023 and the Socioeconomic Status Variable

\begin{tabular}{|c|c|c|c|c|c|}
\hline & & $\mathrm{N}$ & $\bar{x}$ & SD & $p$ \\
\hline \multirow{4}{*}{ Being aware of the document } & High & 114 & 1.75 & .646 & \multirow{4}{*}{.008} \\
\hline & Middle & 76 & 1.64 & .559 & \\
\hline & Low & 171 & 1.92 & .731 & \\
\hline & Total & 361 & 1.81 & .679 & \\
\hline \multirow{4}{*}{ Being aware of the slogan } & High & 114 & 1.98 & .862 & \multirow{4}{*}{.000} \\
\hline & Middle & 76 & 1.89 & .741 & \\
\hline & Low & 171 & 2.39 & 1.008 & \\
\hline & Total & 361 & 2.16 & .937 & \\
\hline \multirow{4}{*}{ Being aware of the vision sentence } & High & 114 & 1.91 & .837 & \multirow{4}{*}{.000} \\
\hline & Middle & 76 & 1.91 & .897 & \\
\hline & Low & 171 & 2.33 & .993 & \\
\hline & Total & 361 & 2.11 & .947 & \\
\hline \multirow{4}{*}{ Giving opinion to the vision } & High & 114 & 3.44 & 1.048 & \multirow{4}{*}{.000} \\
\hline & Middle & 76 & 2.80 & 1.327 & \\
\hline & Low & 171 & 3.65 & .935 & \\
\hline & Total & 361 & 3.41 & 1.109 & \\
\hline \multirow{4}{*}{ Participating in vision meetings } & High & 114 & 3.46 & 1.107 & \multirow{4}{*}{.000} \\
\hline & Middle & 76 & 2.95 & 1.326 & \\
\hline & Low & 171 & 3.82 & .956 & \\
\hline & Total & 361 & 3.52 & 1.138 & \\
\hline \multirow{4}{*}{ Excited for the vision } & High & 114 & 2.39 & 1.061 & \multirow{4}{*}{.003} \\
\hline & Middle & 76 & 2.26 & 1.136 & \\
\hline & Low & 171 & 2.71 & .997 & \\
\hline & Total & 361 & 2.52 & 1.062 & \\
\hline \multirow{2}{*}{ Supporting the vision } & High & 114 & 1.77 & .704 & \multirow{2}{*}{.001} \\
\hline & Middle & 76 & 1.59 & .715 & \\
\hline
\end{tabular}




\begin{tabular}{|c|c|c|c|c|c|}
\hline & \multirow{2}{*}{$\begin{array}{l}\text { Low } \\
\text { Total }\end{array}$} & \multirow{2}{*}{$\begin{array}{l}171 \\
361\end{array}$} & \multirow{2}{*}{$\begin{array}{l}1.97 \\
1.83\end{array}$} & \\
\hline & & & & .781 & \\
\hline \multirow{4}{*}{$\begin{array}{l}\text { Believing in the effectiveness of measurement } \\
\text { methods }\end{array}$} & High & 114 & 2.24 & .790 & \multirow{4}{*}{.000} \\
\hline & Middle & 76 & 2.03 & .894 & \\
\hline & Low & 171 & 2.49 & .836 & \\
\hline & Total & 361 & 2.31 & .852 & \\
\hline \multirow{4}{*}{$\begin{array}{l}\text { Believing in the effectiveness of evaluation } \\
\text { methods }\end{array}$} & High & 114 & 2.25 & .782 & \multirow{4}{*}{.000} \\
\hline & Middle & 76 & 2.00 & .894 & \\
\hline & Low & 171 & 2.51 & .829 & \\
\hline & Total & 361 & 2.32 & .850 & \\
\hline \multirow{4}{*}{$\begin{array}{l}\text { Being aware of the social development of the } \\
\text { student }\end{array}$} & High & 114 & 1.88 & .626 & \multirow{4}{*}{.000} \\
\hline & Middle & 76 & 1.83 & .773 & \\
\hline & Low & 171 & 2.22 & .758 & \\
\hline & Total & 361 & 2.03 & .743 & \\
\hline \multirow{4}{*}{$\begin{array}{l}\text { Being aware of the cultural development of the } \\
\text { student }\end{array}$} & High & 114 & 1.89 & .662 & \multirow{4}{*}{.000} \\
\hline & Middle & 76 & 1.79 & .736 & \\
\hline & Low & 171 & 2.25 & .805 & \\
\hline & Total & 361 & 2.04 & .774 & \\
\hline \multirow{4}{*}{$\begin{array}{l}\text { Being aware of the physical development of the } \\
\text { student }\end{array}$} & High & 114 & 1.93 & .700 & \multirow{4}{*}{.000} \\
\hline & Middle & 76 & 1.82 & .812 & \\
\hline & Low & 171 & 2.26 & .828 & \\
\hline & Total & 361 & 2.06 & .807 & \\
\hline \multirow{4}{*}{$\begin{array}{l}\text { Believe that the student is relieved of the test } \\
\text { pressure }\end{array}$} & High & 114 & 2.54 & .970 & \multirow{4}{*}{.010} \\
\hline & Middle & 76 & 2.25 & .881 & \\
\hline & Low & 171 & 2.64 & .919 & \\
\hline & Total & 361 & 2.53 & .937 & \\
\hline \multirow{4}{*}{$\begin{array}{l}\text { Believing that vision drives healthy data flow in } \\
\text { school }\end{array}$} & High & 114 & 2.64 & .923 & \multirow{4}{*}{.000} \\
\hline & Middle & 76 & 2.28 & 1.066 & \\
\hline & Low & 171 & 2.87 & .945 & \\
\hline & Total & 361 & 2.67 & .989 & \\
\hline
\end{tabular}




\begin{tabular}{lllllll}
\hline & High & 114 & 3.13 & 1.026 & \\
Believing that vision contributes to a professional & Middle & 76 & 2.57 & 1.147 & .000 \\
career plan & Low & 171 & 3.43 & .933 & \\
& Total & 361 & 3.15 & 1.060 & \\
\hline & High & 114 & 2.88 & .942 & \\
& Middle & 76 & 2.29 & .991 & .000 \\
$\begin{array}{l}\text { Believing that vision provides proficiency in } \\
\text { measuring }\end{array}$ & Low & 171 & 3.04 & .880 & \\
& Total & 361 & 2.83 & .965 & \\
\hline & High & 114 & 2.86 & .911 & \\
& Middle & 76 & 2.25 & .981 & .000 \\
$\begin{array}{l}\text { Believing that the vision provides competence in } \\
\text { evaluation }\end{array}$ & Low & 171 & 3.05 & .856 & \\
& Total & 361 & 2.82 & .950 & \\
\hline
\end{tabular}

A significant relationship was found between the opinions of the teachers participating in the study on the 2023 Education Vision and the socioeconomic status variable. Accordingly, the perception levels of teachers with different socioeconomic status regarding the 2023 Education Vision are not the same. It is observed that the belief of the teachers in high socioeconomic level and the low socioeconomic level in vision is higher, and the belief of the teachers in the middle socioeconomic level, which constitutes the vast majority, is lower than the others.

\section{Discussion}

The 2023 Education Vision Document is an important document in terms of being a declaration of purpose and will, determining the main ways to go and determining the main problems of education in a written document. The objectives in the document in question clearly raise the necessity of an important cultural transformation at various scales and levels. The objectives in the 2023 Education Vision document clearly raise the need for an important cultural transformation at various scales and levels. Priorities such as data-based decision processes, making it widespread throughout the country after applications and pilot studies, changing the meaning attached to the assessment and evaluation approach, and reaching the power of the school to determine its own priorities point to a different approach than it has been before.

Within the scope of this study, it was concluded that the vision document had a positive effect on the managers. The document brought a new vision to the education system. The vision document has brought significant innovations and changes with it. It is important to report innovative ideas over existing problems. Education administrators and teachers stated that the changes such as workshops, number of lessons, programs, and break times are appropriate for secondary education and basic 
education programs. The issues that are considered negatively by teachers are issues such as the problem of paid teaching, unconsciousness, being short-term, slow functioning, anxiety in terms of quality, efficiency in lessons, concerns about implementation, impossibility in the city and region. Within the scope of this study, it was concluded that the vision document had a positive effect on the managers. It is important to report innovative ideas over existing problems. Education administrators and teachers stated that the changes such as workshops, number of lessons, programs, and break times are appropriate for secondary education and basic education programs. The issues that are considered negatively by teachers are issues such as the problem of paid teaching, unconsciousness, being shortterm, slow functioning, anxiety in terms of quality, efficiency in lessons, concerns about implementation, impossibility in the city and region.

A meaningful and positive relationship was found between the income levels of the teachers and school administrators participating in the study and their attitudes and views on the 2023 education vision. Accordingly, it is understood that participants with higher income levels have higher beliefs in vision and are more hopeful. In addition, these findings were determinative in terms of the results of this study. It is understood that income levels should be improved in order to receive support for the vision effort of the educators. This result was also supported by Dogan (2019). In many other studies, it has been stated that the concept of vision in education is to take many improving, regulatory and developing steps towards education in order to increase the quality of education (Sendag \& Gedik, 2015).

Considering the international sources, it is seen that the expectations and practices regarding education systems are in line with the content of the 2023 Education Vision document. This shows that the 2023 Education Vision document has not only local criteria but also international criteria. Accordingly, Wong (2003) emphasizes a lifelong learning culture, a learning-oriented education system, and promoting quality education; Spasenovic and Maksic (2013) stated that the characteristics of the social context in which education reform takes place should be taken into account; Chan (2000) collaborates for systemic changes in the success of education reform, respect for diversity and choice, ensure the pursuit of equal excellence, talent and skills-based development programs, encourage research in the field of education; Ginsburg, Moseley, and Pigozzı (2010) emphasized a human-oriented education approach, the protection of human rights, and the consideration of national and global values; Anderson, Brown, and Lopez-Ferrao (2003) encourage politicians and educators to cooperate and act with other institutions; Kazan-Awanis, Hazlina, Yoke-May, and Zariyawati (2011) Successful teachers who have acquired problem solving skills, think independently, collaborate, provide students with different learning and teacher strategies; Chang (2009) support of politicians, democratization, prevention of political concerns; King (2011) employs adequate resources and appropriate governance and responsibility mechanisms guiding this, enabling all stakeholders to benefit from changes in education; Marques and Bannon (2003), Kaufman (2003) to be prepared for conflicts and resistances in the reform process; Yuda and Itoh (2006) emphasizes that the curriculum is made to include students 'and students' interests or ideas, and the effective use of resources Chu (2007) emphasizes the modern school system. Families and other education stakeholders can be informed and made aware of the 2023 Education Vision. It is possible to make the following recommendations regarding the 2023 Education Vision Document as the result of this study and as a result of the interactions and observations that took place during the research. 
Even if teachers and school administrators express their positive opinions about the 2023 Education Vision, some negative opinions can be minimized by sharing the vision again with the slogan of "we believed, you believe too", and action can be taken immediately for the 2033 Education Vision. In this direction, female administrators can be made obligatory in school administrations to highlight their positive energies and beliefs. School administrators can be chosen from among those with a leader temperament who can own and share the vision. In the selection of school administrators, individuals who speak a foreign language, have academic competence, and related professions in fields such as arts, sports and music, or unique personality types can be paved. School administration can be opened up to who are not teachers, contracted and outside of the profession. Teaching academics can be encouraged. Various motivation studies can be done for teachers to feel valuable. Ministerial-level studies can be carried out to increase the acceptance of the profession by young teachers, their vision beliefs and educational belonging. The date "April 23, 2023" can be set as a turning point for each school to plant its own unique corporate culture seed. Teachers' salaries can be improved and weekly lesson hours can be reduced. Starting with the Covid-19 epidemic, the distance learning and the EBA system which has been started to be tested, can be further developed and a personalized digital connection and security model can be developed by the Ministry of National Education. Remote control of learning can be made more realistic. In other possible epidemic situations, teachers can legally be allowed to work remotely without interrupting education and training. Educational materials could be completely redesigned in the context of the 2023 Education Vision.

In addition, by strengthening the data recording systems of schools, the data stored there can be made compatible with contemporary corporate governance and digital innovations. The data in question can be made available to administrators, teachers, parents, students and other stakeholders through robust, clear and secure criteria and control systems, taking into account the protection of personal data, ensuring exam security and similar systemic vulnerabilities. Scientific and holistic solution approaches can be brought to the fore with a data-based management model.

Assessment and evaluation models can be evaluated in student achievement of non-examination skills targeted in the 2023 Education Vision Document. It can be ensured that measurement tools developed in accordance with learning models by doing and experiencing are used actively. In basic education, activities that do not include exams that will enable students to reveal their talents at an early age can be increased. In determining the lessons that students will take, realistic and faithful arguments such as belief, family, cultural environment, employment opportunities and needs of the place, prioritizing activities that support ecological balance can be put forward, and life can be ensured to remain in the course and the course in life.

\section{References}

Akkoyunlu, B. (2002). Educational technology in Turkey: Past, present and future. Educational Media International, 39(2), 165-174. DOI: 10.1080/09523980210155352

Akyuz, Y. (2011). Turkish Education History. Ankara: Pegem A Akademi Publications. 
Anderson, T. (2003). Getting the mix right again: An updated and theoretical rationale for interaction. The International Review of Research in Open and Distance Learning, 4(2), 1-14. DOI: 10.19173/irrodl.v4i2.149

Anderson, T. (2003). Getting the mix right again: An updated and theoretical rationale for interaction. The International Review of Research in Open and Distance Learning, 4(2), 1-14. DOI: 10.19173/irrodl.v4i2.149

Başaran, M. (2003). The use of teaching materials in Turkish lessons by teachers in primary education 4th and 5th grades. (Master Thesis). Accessed from YOK (the council of higher education) Thesis Center database (Thesis No: 133819).

Coskun, S. (2001). Material/technology usage situation in primary school 4th and 5th grade social studies lesson. (Master Thesis). Accessed from YOK (the council of higher education) Thesis Center database (Thesis No: 106748).

Cagiltay, K., Cakiroglu J., Cagiltay N., \& Cakiroglu E. (2001). Teachers' views on computer use in teaching. Hacettepe University Journal of Education, 21, 19-28. Access address: https://dergipark.org.tr/tr/

Celik, V. (1995). Educational management in theory and practice. Ankara: Pegem Academy Publishing.

Dursun, F. (1999). Determination of teachers' competencies and educational needs for computer-aided teaching (Master's Thesis). Accessed from YOK (the council of higher education) Thesis Center database (Thesis No: 81711).

Ercetin, S. S. (2000). Vision in leader spiral. Ankara: Nobel Publishing.

General Directorate of Education Reform (2011). Education Monitoring Report. Ankara: General Directorate of Education Reform Publications.

Eroldogan, A. Y. (2007). Primary Education II. Investigation of the level of using instructional technologies of branch teachers in senior schools according to some variables (Master's Thesis). Accessed from YOK (the council of higher education) Thesis Center database (Thesis No: 206407).

Ergun, M. (2018). The birth and development of modern education systems (Vol. 1). Ankara: Pegem A Academy Publications.

Erturk, A. (2019). Is the 2023 Education Vision the answer to the problems? Pamukkale University Journal of Education, 48, 321-345. DOI: 10.9779 / pauefd.537273

Fidan, N. K. (2008). Teachers' views on the use of equipment in primary education. Journal of Theoretical Educational Science, 1(1). 48-61. https://dergipark.org.tr/tr/

Gomleksiz, M. N. (2004). Use of education technology in English classes. The Turkish Online Journal of Educational Technology, 3(2), 11. http://www.tojet.net/articles/

Guven, İ. (2001). The international dimension of teacher training. National Education Journal, 150, $20-27$. http://dhgm.meb.gov.tr/yayimlar/dergiler/Milli_Egitim_Dergisi/

Hamarat, E., \& Arkan, A. (2018). Future skills in the 2023 Education Vision Document. Seta Perspective Magazine, 222, 1-7. https://setav.org/assets/uploads/ 
Kaya, Z. (2006). Instructional technologies and material development. Ankara: Pegem A Publishing.

Kocasarac, H. (2003). Teacher qualifications regarding the use of computers in teaching. The Turkish Online Journal Of Educational Technology, 2(3), 1-9. http://www.tojet.net/articles/

Collective (1991). Contemporary developments in educational sciences. Eskisehir: Open Education Faculty Publications.

Ozhelvac1, H. (2003). Levels of teachers working in the districts of Sakarya province using educational technologies (Master's Thesis). Accessed from YOK (the council of higher education) Thesis Center database (Thesis No: 136927).

Senge, P. M. (1993). Fifth Discipline (A. Ildeniz and A. Dogukan, Trans.). Istanbul: Yapi Kredi Publications. (Original work published in 1990).

Ozpinar, İ., \& Arslan, S. (2008). Teacher qualifications: The expectations of primary education programs and the gains of education faculties. Necatibey Faculty of Education Electronic Science and Mathematics Journal, 1(1), 38-63. https://dergipark.org.tr/tr/

Sahin, M. (2000). Problems faced by classroom teachers while performing activities related to educational technologies and applications in the teaching process. (Master Thesis. Accessed from YOK (the council of higher education) Thesis Center database (Thesis No: 102171).

Sisman, M. (2002). Instructional leadership. Ankara: Pegem A Publishing.

Turkish Language Association (t.y.). Turkish Dictionary. Accessed on 02.12.2020 from https://sozluk.gov.tr/).

Ucar, M. (1998). Evaluation of teachers' views on the use of course materials in primary education (Master's Thesis). Accessed from YOK (the council of higher education) Thesis Center database (Thesis No: 64834)

Usun, S. (2006). Instructional technologies and material design. Ankara: Nobel Publishing.

Weis, A. H., Mandich, M., Seidenberg, I., Odom, R. D., Conn, C., Pfeiffer, E., ... \& Spoon, A. G. (1999). Professional development: A link to better learning. School, Technology and Readiness Report.

Yilmaz, M. (2007). Technology education in training classroom teachers. Gazi Faculty of Education Journal, 27(1), 155-167. http://www.gefad.gazi.edu.tr/tr/ 